\title{
Mega-Para-Sporting Event Social Impacts Perceived by Tokyo Residents: Comparison of Residents' Vitality
}

\author{
Rei Yamashita (D)
}

Faculty of Sport Sciences, Waseda University, Nishitokyo, Tokyo 202-0021, Japan; rei-yamashita@aoni.waseda.jp; Tel.: +81-42-451-1071

\begin{abstract}
There is a global shift in hosting international sporting events, and this is insisted to have social impacts on the host residents and increase their vitality and empowerment. From the academic perspective, numerous studies have revealed the social impacts of hosting mega-sporting events in several contexts. However, research remains scarce in the area of mega-para-sporting events. Therefore, this study examines the relationship between residents' perceived social impact and supporting intention. Additionally, comparing the levels of vitality were also revealed. Conducting a confirmatory factor analysis and structural equation modelling using group comparison, this study revealed educational benefits as a new insight for hosting a para-sporting event, and their perception differed by the residents' vitality level. Theoretical and practical implications are discussed.
\end{abstract}

Keywords: mega para-sporting events; social impacts; vitality; residents

\section{Introduction}

There is a global shift in hosting international sporting events by countries outside

Citation: Yamashita, R.

Mega-Para-Sporting Event Social Impacts Perceived by Tokyo

Residents: Comparison of Residents' Vitality. Sustainability 2021, 13, 9311.

https://doi.org/10.3390/su13169311

Academic Editor: Kyle

Maurice Woosnam

Received: 25 June 2021

Accepted: 16 August 2021

Published: 19 August 2021

Publisher's Note: MDPI stays neutral with regard to jurisdictional claims in published maps and institutional affiliations. the Western world [1]. Over the last century, mega-sporting events have been hosted predominantly in the Western world that are mostly developed countries. In recent years, however, the hosting of mega-sporting events has started shifting to developing countries. A prime example is the 2008 Beijing Summer Olympic and Paralympic games [2]. This shift has become more prevalent. For example, after its success in hosting the 2018 Asian Games, Indonesia expressed an interest in hosting the first Summer Olympic Games in Southeast Asia in 2032 as an opportunity to showcase its economic power [3]. Hosting mega-sporting events will showcase the economic power. However, hosting a mega-sporting event creates an opportunity to change their residents' lives, and has expanded worldwide [4]. Scholars [1] have suggested that the opportunity of hosting will facilitate an understanding of what is needed for social development within the host city and the country. According to Dashper and Fletcher [5], sporting events can play a role in (re)articulating structural inequalities in society, including disability sport. Thus, hosting a sporting event will have to involve the residents who directly support the event before, during, and after. The residents' support is a critical barometer for the public policies and regulations [6], and when the scale of the sporting event increases, their support will be more critical than other public projects because their support can transform a sporting event into urban festivals [7]. Thus, residents' support for hosting a mega-sporting event is a precondition that will contribute to hosting the sporting event through community involvement.

A secondary, often significant, purpose of organising a sporting event is to vitalize residents in the community. Vitalized people are more active, productive, cope better with stress and challenges, and report greater mental health (e.g., [8,9]). Additionally, they are more resilient to physical and viral stressors and less vulnerable to illness (e.g., [10-12]). Several studies which have investigated that spectating sport can vitalize and make people happier [13,14], yet the link between sporting events and happiness and vitality is far less understood [15]. An example of a sporting event that offers host residents opportunities to learn and accomplish social inclusion and sustainability is the Paralympic Games [16]. 
The Paralympic Games has contributed to the enlargement during recent decades, which are more numerous and diverse. The Paralympic movements assisted from the political and institutional perspective at an international level to promote equal treatment between sport for people with disabilities and sport for people without disabilities [17]. Several studies have conducted the leverage of Paralympic Games (e.g., London 2012 and Rio 2016) given to the disabled people $[18,19]$; however, to the authors' knowledge, no study has just examined the residents' perceptions towards para-sporting events. Residents' perceptions are relevant to focus on since those who are more involved in their community will become active supporters of community events. These statements should also be accumulated in the context of para-sporting events. Therefore, the local authorities must get residents involved in their community activities, improving residents' empowerment and social stability [20].

The purpose of the current research is to examine the relationship between residents' perceived social impacts from hosting the mega para-sporting event and their support intention towards future para-sporting events. This research also examines how the perception towards the relationship between impacts and supporting intention differs between residents' vitality levels. Revealing the difference between these will contribute to the policymakers seeking to utilize sporting events to make the community energetic and vitalized. In the following sections, we first review existing literature and establish the theoretical framework for this study. As mentioned earlier, extant studies on para-sporting event perceptions in sport management and marketing research remain scarce [21], which this study seeks to fill in the knowledge gap. The inference is made from studies on ablebodied mega-sporting events (e.g., Olympic Games). Following this, the paper proceeds as a literature review, including the theoretical background and proposes the research hypotheses. Next will be methodologies, followed by empirical results and concluding remarks.

\section{Literature Review}

\subsection{Theoretical Framework}

Social exchange theory is one of the most popular theories adapted to social impact studies [22]. The rationale behind this theory is to describe the behavioural interactions between two or more individuals and how these behavioural interactions reinforce the other's behaviour, which actors, on this basis, would exchange benefits for both [23]. This theory is applied to the residents' perception of mega-sporting events, which explained that residents are willing to become involved in a social exchange if the perceived benefits outweigh the involvement costs [24]. This theory provides a way to understand the differentiated perceptions of the residents [25,26]. According to Ap [25], an individual's attitude towards a mega-sporting event and the subsequent levels of support for hosting the same and/or similar will be influenced by residents' evaluation of the outcomes in the community. In other words, an individual who perceives more benefits from an exchange is more likely to evaluate it positively and vice versa. The use of social exchange theory in the context of mega-sporting events suggests that residents' attitudes can be explained by the exchange of benefits and what they can receive from the event [27].

An additional theory introduced in this study is the demonstration effect, which refers to a more direct effect on individuals [28]. The demonstration effect (also known as the trickle-down effect) underpins governments' policy making, especially for elite sport. This theory explains the performances of elite athletes at sporting events that inspire others to become active and partake in sport [29]. As Weed [30] mentioned, this theory elucidates how people are prompted to participate in physical activity and sport through inspiration from elite sport, athletes, or sport events. However, the demonstration effect is largely anecdotal since it lacks empirical evidence [31,32]. Thus, little is known about how a mega-sporting event affects a spectator's behaviour, more so in the context of the parasporting event. Potwarka et al. [32] have suggested that the knowledge of cognitive and affective characteristics of spectators' experience (e.g., thoughts, feelings, and emotions) 
that influence people's participatory responses to an event may help design leverage strategies in mega-sporting events. Such a demonstration effect can potentially enhance spectating residents' emotions to live with high vitality and empower them daily.

By combining these two theories, it is plausible that host residents can benefit from the social impact of a para-sporting event through getting motivated by spectating paraathletes who have disabilities and overcoming the physical challenges. Additionally, this study seeks to understand if the perceived social impacts will differ by their vitality levels. It could indicate a new message (e.g., seeing para-athletes succeeding enhances hosting residents' vitality) for hosting the para-sporting event for the future. Therefore, it is reasonable to expect that an individual with a strong vitality is likely to perceive that they have received more benefits than those with lower vitality from the demonstration effects of mega-sporting events.

\subsection{Relationship between Social Impacts and Residents' Support in Mega-Sporting Events}

The financial contribution of mega-sporting events towards the economic development of the host city and/or country is increasingly debatable owing to the escalating costs [33]. There has thus been a drastic shift in recent years by candidate cities to consider the social impacts to be gained from hosting the mega-sporting event as they are arguably more important than the economic benefits [34]. Studies suggest that positive social impacts are viewed as more critical than economic impacts by residents of host communities [35-37]. Considering social impacts rather than economic benefits is explained by the bidding and planning process of mega-sporting events, which tend to be politically charged with minimal involvement and input from residents who may not receive any economic benefits from the development [38]. Moreover, the social impacts of mega-sporting events are essential to any successfully organised sporting event [37].

In their study, Inoue et al. [39] suggest that unique sporting events such as charityaffiliated sporting events can benefit disabled community members. Events like these generate social impacts through the inclusion of disabled residents in the community. Moreover, sporting events like these can activate community behavioural change towards a specific population, such as the disabled community, through para-sporting events [16,20]. An additional study by Inoue et al. [40] proposed four dimensions of social impactscommunity excitement, community attachment, event excitement, and community pride. By hosting a charity-related sporting event, the unique sporting event generated a higher social impact for spectators. This study demonstrated that residents were more likely to support the unique and special events (e.g., Paralympic Games) if they perceived a higher level of social impact from the event [40].

It is critical to understand residents' attitudes towards any form of mega-sporting event development. Understanding the event's impact and residents' support intentions is essential to the success of any sporting event [41]. Assessing the level of support from the residents and understanding the antecedents of their support are crucial to local governments, policymakers, and businesses [42]. Regardless of residents' previous attitudes, once the bid is won, the involvement and support of all stakeholders, including residents, is critical [43]. Studies suggested that for those who perceived higher social impacts, the stronger their support for hosting mega-sporting events get [38,43]. Accordingly, the following hypotheses were proposed as follows:

Hypothesis 1 (H1). Community excitement has a positive influence on intention to support the para-sport event.

Hypothesis 2 (H2). Community attachment has a positive influence on intention to support the para-sport event.

Hypothesis 3 (H3). Community pride has a positive influence on intention to support the parasport event. 
Hypothesis 4 (H4). Event excitement has a positive influence on intention to support the parasport event.

Cultural benefits such as educational impacts are critical social impacts from sporting events [44]). A study conducted on Formula Grand Prix revealed the plethora of cultural benefits that could be anticipated by hosting a mega-sporting event. First of all, volunteers and helpers could obtain additional knowledge and skills, including service and event management, through training for and supporting the event as volunteers. Second, since events include a wide range of attendees from different regions and/or countries, one's horizon would be broadened with new knowledge and inspirations [45,46]. Dwyer and colleagues argue that special events held in local communities allow residents to exchange ideas and serve as an educational platform for residents [46]. These studies confirmed educational value opportunities that local people can expect from hosting major sport events [47]. Hence, the following hypothesis is put forth:

Hypothesis 5 (H5). Cultural/educational benefit has a positive influence on intention to support the para-sport event.

\subsection{Vitality}

Vitality is a straightforward concept in most countries [9]. According to Ryan and Deci [48], vitality is classically defined as having physical and mental energy, and those who are vital experience a sense of enthusiasm, aliveness, and energy to the self [9]. The study on well-being is a popular research topic where two principal approaches lead its discussion-hedonic and eudaimonia approaches, where vitality is included in the latter [49]. Vitality is adapted in the self-determinant theory [49], which describes the central definitional aspect of well-being and attempted to specify what it means to actualize the self and how that can be accomplished. Autonomy, competence, and relatedness are the three basic psychological needs for human beings, which are essential for experiences of vitality [8]. Fulfilling the psychological needs is viewed as a natural aim of human life that exposits many of the meanings and purposes underlying human action [50]. In this aspect, scholars in sport management have only started to understand how sport spectatorship impacts an individual's vitality [13]. Several studies have revealed the team identification is related to levels of vitality $[13,14]$. However, no studies have examined it from the context of mega-sporting event spectatorship. Knowing how psychological energy can be maintained and gained is essential for the individual and the local authorities [48].

Perceptions of the impacts of mega-sporting events differ across the social-demographic profiles because each segment has its social exchange relationships with other stakeholders [27]. However, the difference among residents' sociodemographic variables lacks understanding [51]. Mao and Huang have proposed the necessity to use residents' intrinsic dimensions to help explain the differences among subgroups in the community and resulting reactions to mega-sporting events. In their study, residents' intrinsic dimension strengthened their attitude as their engagement towards the sporting event increased. Additionally, it is stated that individuals' perception of impacts can be examined concerning sociodemographic and socioeconomic variables in festival and event impacts [52]. Festival and event management research has provided insights using the length of residence, educational level, household income, and level of attachment [52]. However, none have examined the level of residents' vitality. Although vitality is strongly affected by social events, which can lead to feeling excited and energized [53], there have not been many studies examining the relationship between residents' vitality and mega-sporting events. Therefore, the following hypothesis is proposed (see Figure 1): 


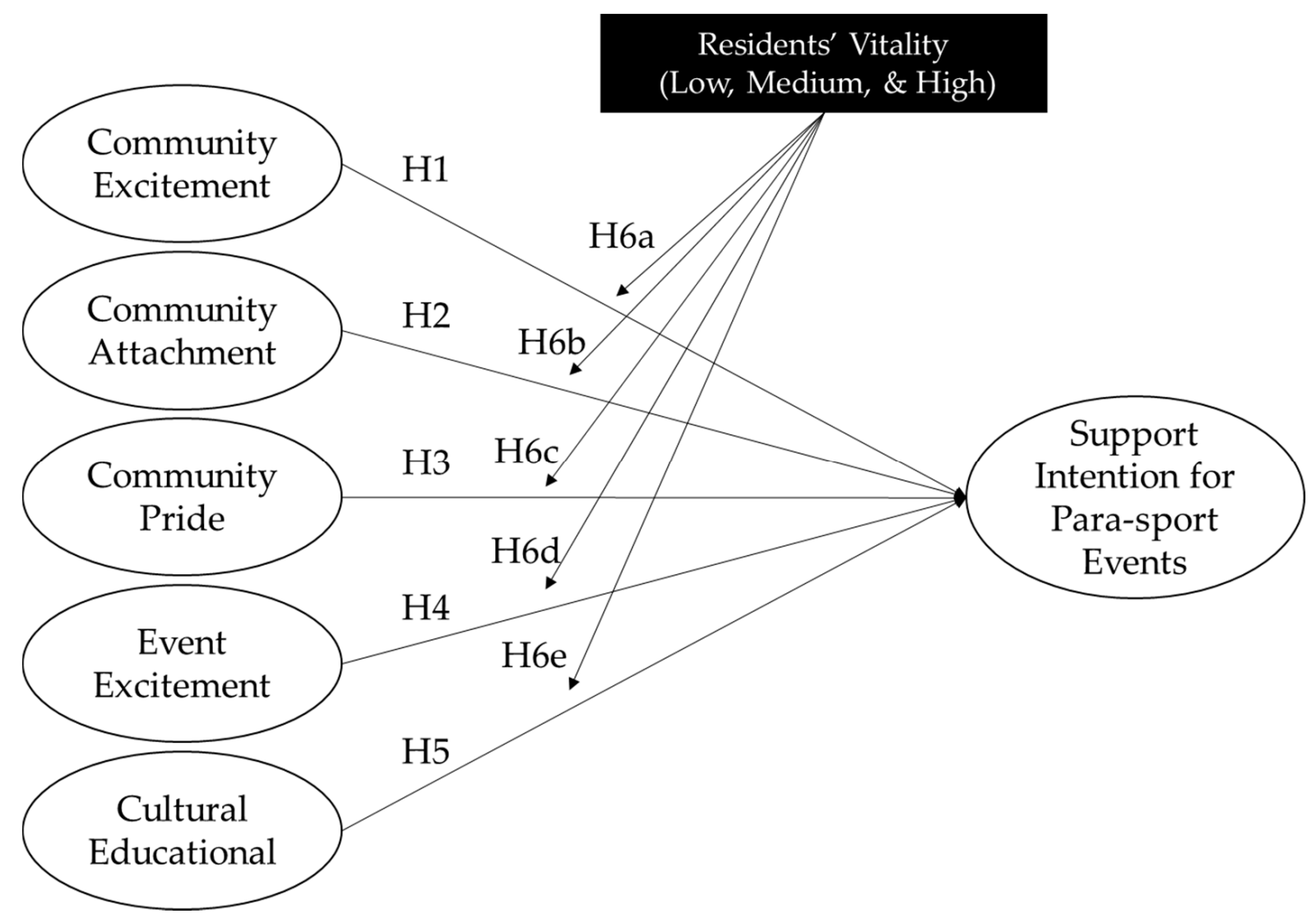

Figure 1. Hypotheses model.

Hypothesis 6 (H6a-e). The vitality perception of residents will moderate the relationship between social impacts and support intention of para-sporting events.

\section{Methods}

\subsection{Data Collection and Samples}

An online questionnaire survey was administered to 1000 residents in the Tokyo prefecture in August 2020, one year before the commencement of the delayed Tokyo 2020 Paralympic Games. The participants were recruited from a large-sized online panel company in Japan, who were filtered at the initial stage down to those who know that the Tokyo 2020 Paralympic Games were postponed to 2021 and did not have a family member who works for the Tokyo Organising Committee of the Olympic and Paralympic Games.

Of the data set of 1000 , the average age was $52.96(\mathrm{SD}=13.41)$, the gender ratio was symmetric $($ male $=50 \%)$, and the average length of Tokyo residence was $34.09(\mathrm{SD}=20.23)$ (see Table 1). 
Table 1. Descriptive statistics of sample characteristics.

\begin{tabular}{|c|c|c|c|}
\hline \multicolumn{2}{|c|}{ Variables } & \multirow{3}{*}{$\begin{array}{c}n \\
500 \\
500\end{array}$} & \multirow{3}{*}{$\begin{array}{c}\% \\
50.0 \\
50.0\end{array}$} \\
\hline & Male & & \\
\hline Gender & Female & & \\
\hline \multirow{8}{*}{ Age } & $10 \mathrm{~s}$ & 6 & 0.6 \\
\hline & $20 \mathrm{~s}$ & 41 & 4.1 \\
\hline & $30 \mathrm{~s}$ & 109 & 10.9 \\
\hline & $40 \mathrm{~s}$ & 221 & 22.1 \\
\hline & $50 \mathrm{~s}$ & 308 & 30.8 \\
\hline & $60 \mathrm{~s}$ & 200 & 20.0 \\
\hline & $70 \mathrm{~s}$ & 94 & 9.4 \\
\hline & over $80 \mathrm{~s}$ & 21 & 2.1 \\
\hline \multirow{2}{*}{ Marriage Status } & Single & 325 & 32.5 \\
\hline & Married & 675 & 67.5 \\
\hline \multirow{7}{*}{ Tokyo residency in years } & less than 5 years & 82 & 8.2 \\
\hline & 6 to 10 years & 85 & 8.5 \\
\hline & $11-20$ years & 166 & 16.6 \\
\hline & $21-30$ years & 127 & 12.7 \\
\hline & $31-40$ years & 130 & 13.0 \\
\hline & $41-50$ years & 168 & 16.8 \\
\hline & $51+$ years & 242 & 24.2 \\
\hline
\end{tabular}

\subsection{Measurements Scale}

The measurement used in this research consisted of three sections: the social impact scale $[40,54]$, which consists of five factors and 14 items, the vitality scale [9], and support for the event, which consisted of three items [47]. All measurements were performed on a 7-point Likert-type scale anchored from 1 (strongly disagree) to 7 (strongly agree). In addition, respondents' demographic information was required. All items introduced were written in English and translated to Japanese; two native speakers checked translation validity. Since the social impacts were measured a year before the mega-sporting event, the items were worded in the future tense, using the self-referenced $[22,55]$.

\subsection{Data Analysis}

The data were analysed using confirmatory factor analysis to check the convergent and discriminant validity of the measurement model. The model fit criteria used in this study were as follows: comparative fit index (CFI $\geqq 0.90$, [56]), Tucker-Lewis Index (TLI $\geqq 0.90,[56])$, root mean square error of approximation (RMSEA $\leqq 0.10,[57])$, standardized root mean square residual (SRMR $\leqq 0.08,[58])$, and chi-square $/ \mathrm{df}\left(\chi^{2} / \mathrm{df} \leqq 5,[58]\right)$. To test the convergent and discriminant validity of the scale, factor loadings $(\lambda \geqq 0.70,[59])$, average variance extracted (AVE $\geqq 0.50$, [59]), and construct reliability (CR $\geqq 0.60,[59])$ were used. The hypotheses model was tested using the structural equation modeling, and after that, the moderating variables were used to compare groups in our hypothesized modeling to test group comparison (i.e., low, medium, and highly vitalized residents).

\section{Results}

\subsection{Measurement Model}

CFA was performed to evaluate the measurement model. While running the first CFA, the factor loadings of correlation between "event excitement" and "community pride" were above 1 , which indicates that these two factors are similar components; we integrated these two constructs and renamed them to "community pride hosting parasporting events". After running the second CFA, the factor loadings for all indicators were above the threshold, and all model fit indices reported an acceptable fit $\left(\chi^{2} / \mathrm{df}=10.130\right.$, 
$\mathrm{CFI}=0.959, \mathrm{TLI}=0.943, \mathrm{RMSEA}=0.096, \mathrm{SRMR}=0.044)$. Next, the convergent validity and construct reliability of the measurement scale were calculated. The AVEs for all the factors ranged from $0.76-0.86$, and CR varied from $0.92-0.95$. Thus, convergent validity and construct reliability were confirmed (see Table 2).

Table 2. Descriptive statistics of each scale.

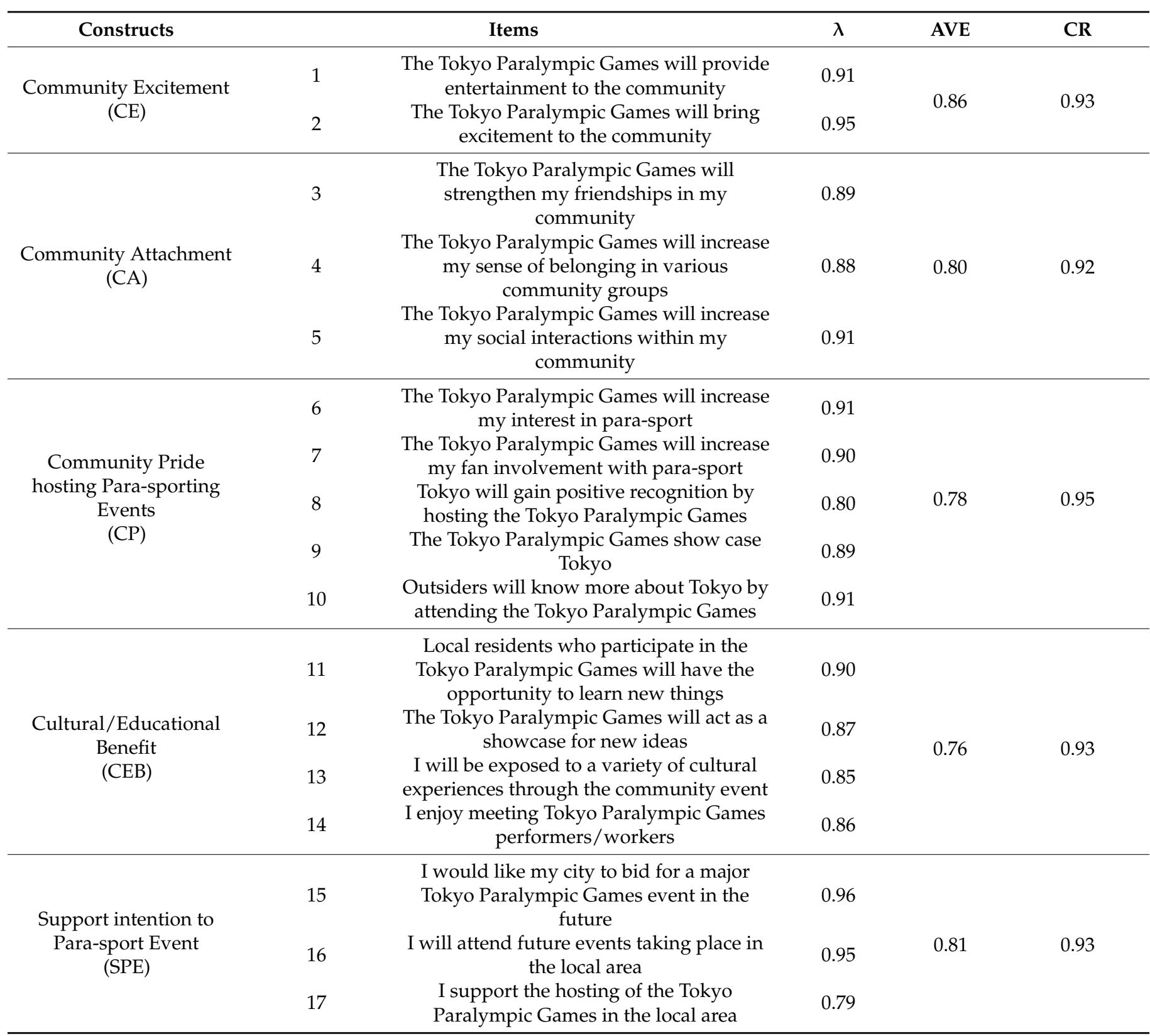

Note: $\chi^{2} / \mathrm{df}=10.130, \mathrm{CFI}=0.959, \mathrm{TLI}=0.943, \mathrm{RMSEA}=0.096, \mathrm{SRMR}=0.044, \mathrm{CR}=$ construct reliability, AVE $=$ average variance extracted .

Next, to test the discriminant validity of the social impact constructs, each AVEs and squared correlations between the variables were compared, indicating acceptable levels. In all, the measurement model successfully fits the dataset (see Table 3). 
Table 3. Comparison of AVEs and squared correlations between the constructs.

\begin{tabular}{cccccc}
\hline Factors & CE & CA & CP & CEB & SPE \\
\hline CE & $0.86 \mathrm{a}$ & - & - & - & - \\
CA & 0.73 & $0.80 \mathrm{a}$ & - & - & - \\
CP & 0.78 & 0.83 & $0.78 \mathrm{a}$ & - & - \\
CEB & 0.76 & 0.77 & 0.84 & $0.76 \mathrm{a}$ & - \\
SPE & 0.61 & 0.65 & 0.67 & 0.78 & $0.81 \mathrm{a}$ \\
\hline
\end{tabular}

Note: $\mathrm{a}=$ AVE. The figures below the AVE line represent squared correlations between the constructs.

SEM was assessed to check the hypothesis model. As presented in Figure 2, the model fit indices showed an acceptable fit with the sample $\left(\chi^{2} / \mathrm{df}=10.517, \mathrm{CFI}=0.957\right.$, $\mathrm{TLI}=0.941, \mathrm{RMSEA}=0.098, \mathrm{SRMR}=0.048) ; 77 \%$ of this was explained by the model The findings indicate significant positive effects from community attachment $(\beta=0.327$, $p<0.001)$ and cultural/educational $(\beta=0.715, p<0.001)$ on support intention for parasport events. However, there were no significant effects toward the dependent variable from community excitement and community pride hosting para-sport events ( $\beta=-0.041$, $p=0.48, \beta=-0.103, p=0.16$, respectively). Thus, Hypotheses 2 and 5 were supported (see Figure 2).

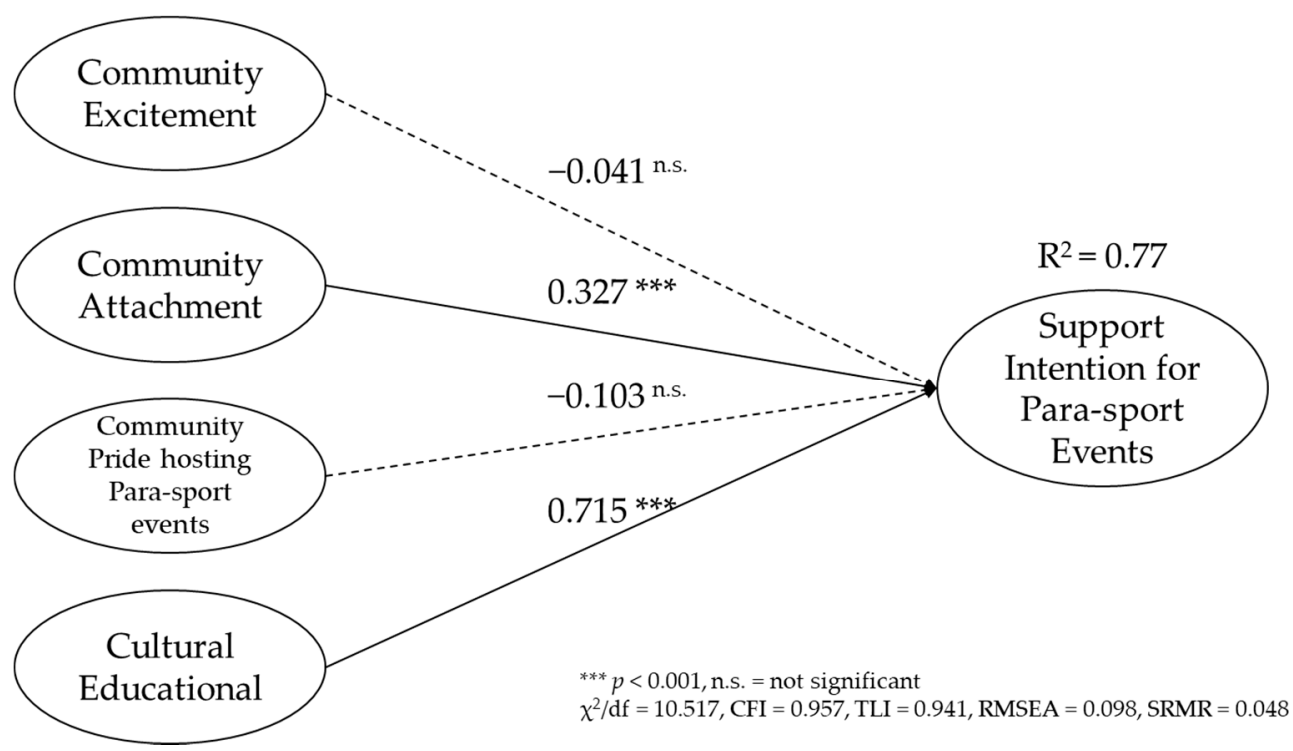

Figure 2. Results of SEM.

\subsection{Group Comparison}

Hypotheses 6a through 6e were tested using multi-group comparison analysis. Before testing the hypothesis, the sample was divided into three groups by calculating residents' vitality scale composite scores into low, medium, and high groups. Those who have scored 1 to 3.43 were labelled 'low vitality group' ( $n=273), 3.44$ to 4.49 labelled 'medium vitality group' ( $n=461)$, and above 4.50 to 7 were labelled 'high vitality group' $(n=277)$. The model fit indices showed a good fit with the sample $\left(\chi^{2} / \mathrm{df}=4.642, \mathrm{CFI}=0.950, \mathrm{TLI}=0.932\right.$, RMSEA $=0.060$, SRMR $=0.063$ ).

First, the measurement invariance test was performed to ensure that measures had the same meanings between the three groups to test the moderating effects of validity. The measurement weight model was built with the factor loadings constrained to be equal between three groups. As shown in Table 4, no statistical significance indicating the measurement invariance between the low, medium, and high vitalized groups was established $\left(\Delta \chi^{2}=4.389, \Delta \mathrm{df}=24, p=0.18\right)$. Next, the chi-square statistic differences between the unconstrained and structural weight models were compared and were statistically significant $\left(\Delta \chi^{2}=4.372, \Delta \mathrm{df}=32, p<0.001\right)$. Hence, the causal links in the structural model had a statistically significant difference between these three groups. 
Table 4. Results of comparing the different paths of the model.

\begin{tabular}{ccccccc}
\hline \multirow{2}{*}{ Direct Effects } & \multicolumn{3}{c}{ Standardized Regression } \\
& Weights & M & H & L vs. $\mathbf{M}$ & L vs. H & M vs. H \\
\cline { 2 - 7 } & $-0.29^{*}$ & $-0.02^{\text {n.s. }}$ & $0.26^{*}$ & 1.627 & $3.231^{* * *}$ & $2.031^{*}$ \\
\hline CE -> Support & $0.18^{\text {n.s. }}$ & $0.36^{* * *}$ & $0.28^{*}$ & 1.055 & 0.468 & -0.584 \\
CA - Support & $-0.23^{\text {n.s. }}$ & $-0.20^{\text {n.s. }}$ & $0.24^{\text {n.s. }}$ & 0.206 & $2.139^{*}$ & $2.532^{* *}$ \\
CP - > Support & $-1.18^{* * *}$ & $0.75^{* * *}$ & $0.15^{\text {n.s. }}$ & -1.595 & $-3.486^{* * *}$ & $-3.826^{* * *}$ \\
CEB -> Support & &
\end{tabular}

Note: measurement weight; $\Delta \chi^{2}=4.389, \Delta \mathrm{df}=24, p=0.18$, structural weight; $\Delta \chi^{2}=4.372, \Delta \mathrm{df}=32, p<0.001$ ${ }^{* * *} p<0.001,{ }^{* *} p<0.01,{ }^{*} p<0.05,{ }^{\text {n.s. }}=$ not significant.

Path analysis was examined to specify the path for which social impacts were perceived different in between low, medium, and high vitalized groups. There was a significant difference in the paths of (a) community excitement $->$ support $\left(\Delta \chi^{2}=4.649, \Delta \mathrm{df}=1\right.$, $p<0.003)(\mathrm{H6a}, \mathrm{b})$ cultural/educational benefit $->\operatorname{support}\left(\Delta \chi^{2}=4.687, \Delta \mathrm{df}=1, p<0.001\right)$ (H6e). The Z-scores were performed to see the group differences carefully. Z-scores higher than 1.96 are significant at $p<0.05$, higher than 2.33 significant at $p<0.01$, and higher than 2.56 significant at $p<0.001$, respectively. For the low vitalized group, community excitement had a negatively significant effect than that of the high vitalized group towards event support $\left(\gamma_{\text {low }}=-0.29, p=0.02, \gamma_{\text {high }}=0.26, p=0.01\right.$, respectively). For the cultural/educational benefit, the low vitalized group had a significantly stronger effect than that of the medium vitalized group $\left(\gamma_{\text {low }}=1.18, p=0.01, \gamma_{\text {medium }}=0.75, p=0.01\right.$, respectively). There was also a significant difference in (c) community pride hosting para-sporting events $->$ support $\left(\Delta \chi^{2}=4.637, \Delta \mathrm{df}=1, p=0.02\right)(\mathrm{H} 6 \mathrm{c}, \mathrm{d})$; however, the path coefficients were not significant $\left(\gamma_{\text {low }}=-0.23, \gamma_{\text {medium }}=-0.20, \gamma_{\text {high }}=0.24\right.$, respectively $)$ There were no significant differences between (d) community attachment $->$ support $\left(\Delta \chi^{2}=4.614\right.$, $\Delta \mathrm{df}=1, p=0.59)(\mathrm{H} 6 \mathrm{~b})$. This model was explained by high percentages of each independent variable (low $=72 \%$, medium $=76 \%$, high $=80 \%$, respectively). Consequently, H6a through H6e were partially supported (see Table 4 and Figure 3).

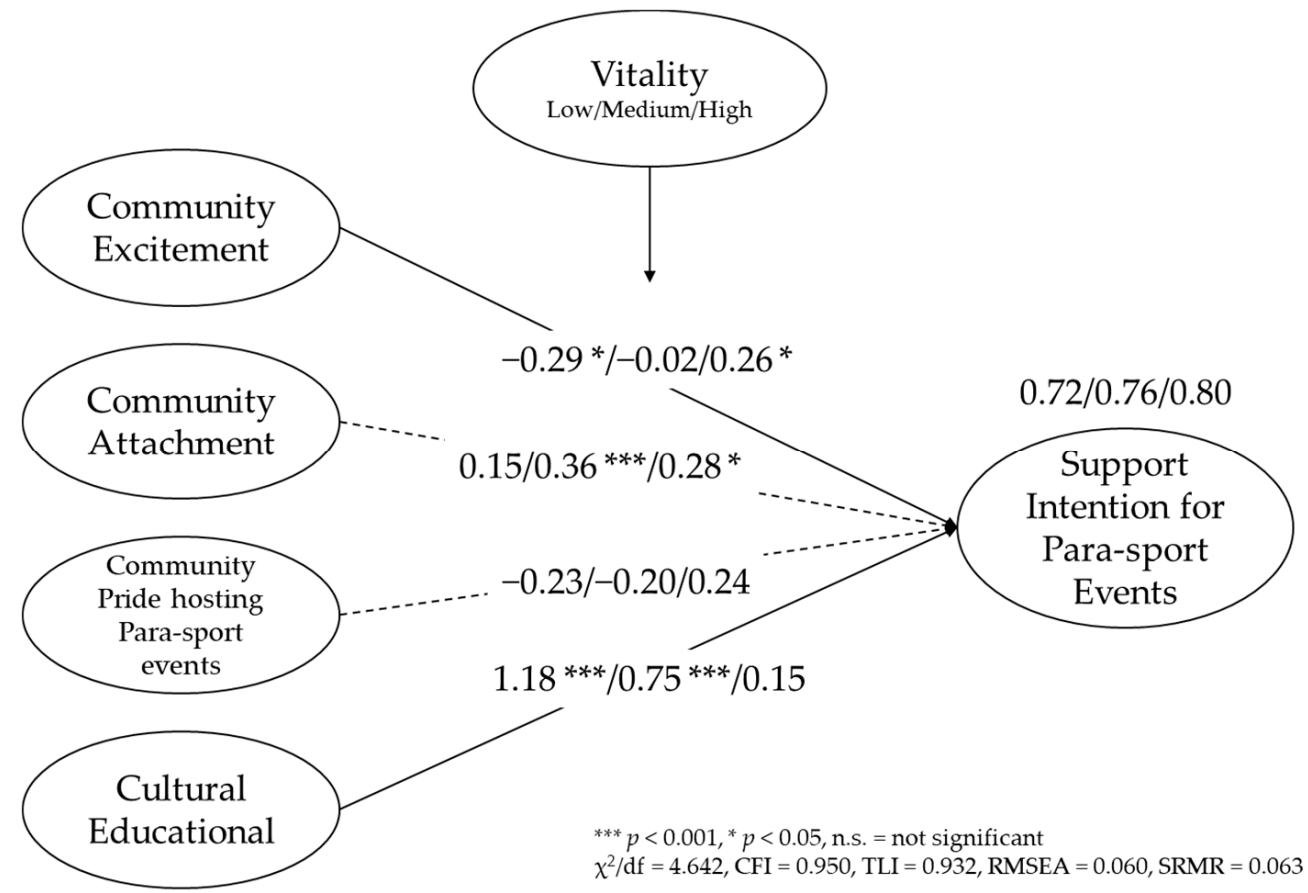

Figure 3. The comparison of path coefficients between three vitality groups. 


\section{Discussion}

Social impacts from mega-sporting events are well-researched; however, discussion on mega para-sporting events remains scarce. Moreover, vitality has attracted extensive interest from scholars, yet has not been considered from the social impact perspective of host residents. To fill these academic gaps, the purpose of this study was to reveal how the residents perceive the social impacts before the actual mega para-sporting event is held. Additionally, residents were divided into their vitality levels, and this study captured how the differing social impacts affect their support intention for para-sport events. The results of multi-group comparison analysis showed that highly vitalized residents perceived more social impacts on community excitement, and those who were low vitalized perceived significantly more cultural and educational benefits than the highly vitalized group. These results provide new insights from both theoretical and practical standpoints.

\subsection{Theoretical Impliactions}

This research made several contributions to existing literature. Social exchange theory remains one of the key theories that look at social impact [22]. The theory asserts that residents are willing to become involved in a social exchange if the perceived benefits outweigh the cost of involvement. Furthermore, this study introduced the demonstration effect, which directly affects individuals [28]. The performances of the elite athletes at the events that inspire others to partake in sport define the demonstration effect in the context of sport [29]. This study has revealed that disabled elite athletes could inspire not only the disabled spectators, but also those who do not have a disability, and the demonstration effect could significantly influence their attitude towards their intention to support mega para-sporting events more than those who are less vitalized. This result ascertains that mega para-sporting events have a demonstration effect towards the spectators regardless of their (dis)ability. Studies that focused on the context of disabled sports' demonstration effect have mostly suggested increased participation of the disabled, mainly 'mythopoeic' [60]. Brown and Pappous [61] have argued the difficulty in using the two-week Paralympic Games to increase sport participation.

Nevertheless, this study described the valuable suggestion that para-sporting events might have the impact of inspiring non-disabled residents through witnessing elite athletes overcoming their disabilities. This result supports a similar study on a charity running event, where cancer survivors participating in a running event provided support and empowered people with cancer. It enabled them to feel inspired and also helped other spectators to overcome difficulties [62].

Additionally, a multi-group comparison was conducted to understand how different residents perceived social impacts and their intentions to support future events. Findings from this study confirm a difference between these three groups-for the highly vitalized group, if they feel the community excitement, their support intention increases; whereas for the low vitalized group, when they perceive cultural and educational benefits, they have a solid intention to support the event. Mega-sporting events (e.g., Olympic Games and Paralympic Games) cannot be planned annually, and the host country is unlikely to host the same event again soon. Owing to the nature of this one-off event, the impact is expected to be received by the residents, especially in motivating those who do not think themselves as an energetic person.

Finally, the social impact perceived by the residents can be categorised into four elements-community excitement, community attachment, community pride hosting parasporting events, and cultural/educational benefit. The social impact components perceived by the residents were different from the original scale; the event excitement and community pride were integrated and renamed as "community pride hosting para-sporting events." These two elements were combined since increasing residents' interest and fan involvement towards the Paralympics will enhance their pride as residents hosting these special megasporting events. This result could be because many Tokyo residents have never spectated para-sporting events before. If they have experienced these events, they can evaluate 
the impacts, particularly how residents will increase their interests in para-sport and be recognized internationally. However, if the residents have never experienced it, they may not distinguish between event excitement and community pride.

Additionally, since the Paralympic Games have been postponed for one year, residents could not imagine how hosting the largest para-sporting event will be looked at from the global perspective during this pandemic occurring worldwide. Moreover, residents could evaluate how they could benefit from hosting a unique context of sport (e.g., para-sporting events), such as by increasing their knowledge and communicate with your community members. Through examining the individual items that made up these elements, they provided new insights into the residents' behaviour (e.g., increased sense of belonging in various community groups, having the opportunity to learn new things, acting as a showcase for new ideas).

\subsection{Practical Implications}

The results from this study have implications for sporting event managers and sport policymakers. This study highlighted that para-sporting events could generate educational and social benefits. Thus, it is necessary to collaborate with the community education program settings. For example, the sporting event can be included in the school educational curriculum and used as an exemplar as school teaching material. By collaborating with the local educational committee, sporting event managers could enhance future leaders who are highly diversity-minded, which will become ubiquitous soon.

Additionally, as mentioned in a previous study that sport spectatorship results in greater vitality and happiness, this study confirms that spectating sport leads to greater vitality [13]. The mega para-sporting event could play a crucial role in vitalizing people, especially those who are low in vitality. Since public health has a serious issue, especially in the number of people committing suicide, because of the pandemic occurring worldwide [63-65], mega-sporting events, and especially para-sporting events, could convey messages towards those who are having concerns in their daily life. Research has implied that high levels of vitality could enhance their subjective well-being [9]. Hence, this study suggests that the para-sporting event could trigger residents to re-think their lives, positively inspired by disabled elite athletes. Resident well-being has been the focal point for many public policies [54]. It is possible to state that mega-para-sporting events will increase resident's vitality. Para-sporting events such as these, not only mega but also non-mega sporting events, should be continued and encouraged.

These results can be helpful information for countries and municipalities that are thinking of inviting mega-sporting events. Especially when it comes to hosting megasporting events, it is imperative to gain support from the residents living in the host city. An overview of the recent Olympic and Paralympic bid process shows that many countries have given up their bid to host mega-sporting events due to opposition from residents (e.g., Stockholm for the 2022 Winter Games, Boston, Hamburg, and Rome for the 2024 Summer Games, and Sion for the 2026 Winter Games). Countries and organizing committees considering hosting the Games in the future can gain public support by using new indicators such as energizing the public, especially those from disabled-elite athletes.

\section{Limitations and Future Research}

There are several limitations to this study. This study has revealed the social impacts perceived before the mega-sporting event; however, the evaluation of event outcomes may not be static, but rather dynamic, which indicates that the resident's evaluation could change as time passes [66]. Residents become more concerned about the negative impacts closer to the event's commencement $[36,66]$. Future studies must create a research design with a two-wave data collection (e.g., [67]). This data collection methodology will capture data on the changes and how the residents have evaluated social impacts (i.e., pre and during the event). 
Additionally, impact perception is associated with both positive and negative impacts [38]. The negative impact could be precepted after the game occurred. It is also important to reveal the negative facets of hosting para-sporting events, which could differ from the non-para sporting context. This study cannot ignore the significant changes driven by COVID-19. The pandemic could be related to the results that perceived social impacts did not significantly affect the dependent variable. Since the indicators included in the factors which did not have a significant effect were related to excitement and recognition from the outsiders, these items might have performed weakly to the support hosting parasporting events in the future. Finally, it is also essential to examine the differences between other socioeconomic variables such as involvement in sport, daily sport participation, previous experience spectating para-sporting events, and other general sociodemographic variables such as length of residency, educational level, and household income [52]. For this study, vitality level was examined using a Likert scale; however, using categorical variables will also be necessary since the Likert scale's dividing dataset has some issues. Examining other variables will enable understanding the role of para-sporting events and how it will change residents' attitudes. These studies will inform society with a deep understanding of disability and create a symbiotic society.

Funding: This research was supported by Waseda University, grant number 2020C-707.

Institutional Review Board Statement: Not applicable.

Informed Consent Statement: Informed consent was obtained from all subjects involved in the study.

Data Availability Statement: The data presented in this study are available on request from the author.

Conflicts of Interest: The author declares no conflict of interest.

\section{References}

1. Dowse, S.; Fletcher, T. Sport mega-events, the 'non-West' and the ethics of event hosting. Sport Soc. 2018, 21, 745-761. [CrossRef]

2. Lamberti, L.; Noci, G.; Guo, J.; Zhu, S. Mega-events as drivers of community participation in developing countries: The case of Shanghai World Expo. Tour. Manag. 2011, 32, 1474-1483. [CrossRef]

3. Nikkei Asia. Indonesia to Bid for 2032 Olympics after Asian Games Success 2018. Available online: https: / / asia.nikkei.com/ Politics/Indonesia-to-bid-for-2032-Olympics-after-Asian-Games-success (accessed on 6 February 2021).

4. Al-Emadi, A.; Kaplanidou, K.; Diop, A.; Sagas, M.; Le, K.T.; Mustafa, S.A.A. 2022 Qatar World Cup: Impact perceptions among Qatar residents. J. Travel Res. 2017, 56, 678-694. [CrossRef]

5. Dashper, K.; Fletcher, T. Introduction: Diversity, equity and inclusion in sport and leisure. Sport Soc. 2013, 16, 1227-1232. [CrossRef]

6. Burstein, P. The impact of public opinion on public policy: A review and an agenda. Political Res. Q. 2003, 56, 29-40. [CrossRef]

7. Santos, G.E.D.O.; Gursoy, D.; Ribeiro, M.A.; Netto, A.P. Impact of transparency and corruption on mega-event support. Event Manag. 2019, 23, 27-40. [CrossRef]

8. Penninx, B.W.; Guralnik, J.M.; Bandeen-Roche, K.; Kasper, J.D.; Simonsick, E.M.; Ferrucci, L.; Fried, L.P. The protective effect of emotional vitality on adverse health outcomes in disabled older women. J. Am. Geriatr. Soc. 2000, 48, 1359-1366. [CrossRef]

9. Ryan, R.M.; Frederick, C. On energy, personality, and health: Subjective vitality as a dynamic reflection of well-being. J. Personal. 1997, 65, 529-565. [CrossRef]

10. Benyamini, Y.; Idler, E.L.; Leventhal, H.; Leventhal, E.A. Positive affect and function as influences on self-assessments of health: Expanding our view beyond illness and disability. J. Gerontol. Ser. B 2000, 55, P107-P116. [CrossRef]

11. Cohen, S.; Alper, C.M.; Doyle, W.J.; Treanor, J.J.; Turner, R.B. Positive emotional style predicts resistance to illness after experimental exposure to rhinovirus or influenza a virus. Psychosom. Med. 2006, 68, 809-815. [CrossRef] [PubMed]

12. Polk, D.E.; Cohen, S.; Doyle, W.J.; Skoner, D.P.; Kirschbaum, C. State and trait affect as predictors of salivary cortisol in healthy adults. Psychoneuroendocrinology 2005, 30, 261-272. [CrossRef] [PubMed]

13. Jang, W.; Ko, Y.J.; Wann, D.L.; Kim, D. Does spectatorship increase happiness? The energy perspective. J. Sport Manag. 2017, 31, 333-344. [CrossRef]

14. Wann, D.L.; Craven, L. Further support for the team identification-social psychological health model: Relationships between identification of college sport teams, vitality, and social avoidance/distress among college students. J. Issues Intercoll. Athl. 2014, $7,352-366$ 
15. Taks, M.; Littlejohn, M.; Snelgrove, R.; Wood, L. Sport events and residential happiness: The case of two non-mega sport events. J. Glob. Sport Manag. 2016, 1, 90-109. [CrossRef]

16. Kolotouchkina, O. Engaging citizens in sports mega-events: The participatory strategic approach of Tokyo 2020 Olympic. Commun. Soc. 2018, 31, 45-58. [CrossRef]

17. Pappous, A.; Marcellini, A.; De Léséleuc, E. From Sydney to Beijing: The evolution of the photographic coverage of paralympic games in five European countries. Sport Soc. 2011, 14, 345-354. [CrossRef]

18. Brittain, I.; Beacom, A. Leveraging the London 2012 paralympic games: What legacy for disabled people? J. Sport Soc. Issues 2016, 40, 499-521. [CrossRef]

19. De Souza, D.L.; Brittain, I. The Rio 2016 paralympic games: The visibility of people with disabilities in Brazil as a possible legacy. Commun. Sport 2020. [CrossRef]

20. Callahan, K. Citizen participation: Models and methods. Int. J. Public Adm. 2007, 30, 1179-1196. [CrossRef]

21. Shapiro, D.R.; Pitts, B.G. What little do we know: Content analysis of disability sport in sport management literature. J. Sport Manag. 2014, 28, 657-671. [CrossRef]

22. Taks, M.; Oshimi, D.; Agha, N. Other versus self-referenced social impacts of events: Validating a new scale. Sustainability 2020, 12, 10281. [CrossRef]

23. Homans, G.C. The humanities and the social sciences. Am. Behav. Sci. 1961, 4, 3-6. [CrossRef]

24. Karadakis, K.; Kaplanidou, K. Legacy perceptions among host and non-host olympic games residents: A longitudinal study of the 2010 Vancouver olympic games. Eur. Sport Manag. Q. 2012, 12, 243-264. [CrossRef]

25. Ap, J. Residents' perceptions on tourism impacts. Ann. Tour. Res. 1992, 19, 665-690. [CrossRef]

26. Gursoy, D.; Jurowski, C.; Uysal, M. Resident attitudes: A structural modeling approach. Ann. Tour. Res. 2002, 29, 79-105. [CrossRef]

27. Waitt, G. Social impacts of the Sydney olympics. Ann. Tour. Res. 2003, 30, 194-215. [CrossRef]

28. Boardley, I.D. Can viewing London 2012 influence sport participation? A viewpoint based on relevant theory. Int. J. Sport Policy Politics 2013, 5, 245-256. [CrossRef]

29. Hindson, A.; Gidlow, B.; Peebles, C. The 'trickle-down' effect of top level sport: Myth or reality? A case study of the Olympics. Aust. J. Leis. Recreat. 1994, 4, 16-24.

30. Weed, M.; Coren, E.; Fiore, J.; Wellard, I.; Chatziefstathiou, D.; Mansfield, L.; Dowse, S. The olympic games and raising sport participation: A systematic review of evidence and an interrogation of policy for a demonstration effect. Eur. Sport Manag. Q. 2015, 15, 195-226. [CrossRef]

31. Misener, L.; Taks, M.; Chalip, L.; Green, B.C. The elusive "trickle-down effect" of sport events: Assumptions and missed opportunities. Manag. Sport Leis. 2015, 20, 135-156. [CrossRef]

32. Potwarka, L.R.; Drewery, D.; Snelgrove, R.; Havitz, M.E.; Potwarka, L.R.; Drewery, D.; Snelgrove, R.; Havitz, M.E.; Mair, H. Modeling a demonstration effect: The case of spectators Experiences at 2015 Pan Am Games track cycling competitions. Leis. Sci. 2018, 40, 1-23. [CrossRef]

33. Gibson, H.J.; Kaplanidou, K.; Kang, S.J. Small-scale event sport tourism: A case study in sustainable tourism. Sport Manag. Rev. 2012, 15, 160-170. [CrossRef]

34. Huang, H.-Y.; Zhang, L. Research note: Estimation of the non-market value of sports events: A case study of the civic pride generated by the 2009 Shanghai ATP masters 1000. Tour. Econ. 2012, 18, 887-895. [CrossRef]

35. Gursoy, D.; Kim, K.; Uysal, M. Perceived impacts of festivals and special events by organizers: An extension and validation. Tour. Manag. 2004, 25, 171-181. [CrossRef]

36. Gursoy, D.; Chi, C.G.; Ai, J.; Chen, B.T. Temporal change in resident perceptions of a mega-event: The Beijing 2008 olympic games. Tour. Geogr. 2011, 13, 299-324. [CrossRef]

37. Prayag, G.; Hosany, S.; Nunkoo, R.; Alders, T. London residents' support for the 2012 Olympic Games: The mediating effect ofoverall attitude. Tour. Manag. 2013, 36, 629-640. [CrossRef]

38. Gursoy, D.; Milito, M.C.; Nunkoo, R. Residents' support for a mega-event: The case of the 2014 FIFA World Cup, Natal, Brazil. J. Destin. Mark. Manag. 2017, 6, 344-352. [CrossRef]

39. Inoue, Y.; Heffernan, C.; Yamaguchi, T.; Filo, K. Social and charitable impacts of a charity-affiliated sport event: A mixed methods study. Sport Manag. Rev. 2018, 21, 202-218. [CrossRef]

40. Inoue, Y.; Havard, C.T. Determinants and consequences of the perceived social impact of a sport event. J. Sport Manag. 2014, 28, 295-310. [CrossRef]

41. Zhang, J.C.; Byon, K.; Xu, K.; Huang, H. Event impacts associated with residents' satisfaction and behavioral intentions: A pre-post study of the Nanjing Youth Olympic Games. Int. J. Sports Mark. Spons. 2020, 21, 487-511. [CrossRef]

42. Hernandez, S.A.; Cohen, J.; Garcia, H.L. Residents' attitudes towards an instant resort enclave. Ann. Tour. Res. 1996, 23, 755-779. [CrossRef]

43. Gursoy, D.; Kendall, K.W. Hosting mega events. Ann. Tour. Res. 2006, 33, 603-623. [CrossRef]

44. Lee, S.P.; Cornwell, T.B.; Babiak, K. Developing an instrument to measure the social impact of sport: Social capital, collective identities, health literacy, well-being and human capital. J. Sport Manag. 2013, 27, 24-42. [CrossRef]

45. Tang, J.; Wang, Y. Does tourism sports event make residents happier?-Exploring the SWB of Macau residents in the case of Macau Grand Prix. J. Tour. Cult. Chang. 2021, 19, 403-421. [CrossRef] 
46. Dwyer, L.; Mellor, R.; Mistilis, N.; Mules, T. A framework for evaluating and forecasting the impacts of special events. In Event Evaluation, Research and Education; Australian Centre for Event Management: Sydney, Australia, 2000; pp. 31-45.

47. Ma, S.C.; Kaplanidou, K. Examining the importance of legacy outcomes of major sport events for host city residents' quality of life. Appl. Res. Qual. Life 2016, 12, 903-923. [CrossRef]

48. Ryan, R.M.; Deci, E.L. From ego depletion to vitality: Theory and findings concerning the facilitation of energy available to the self. Soc. Personal. Psychol. Compass 2008, 2, 702-717. [CrossRef]

49. Ryan, R.M.; Deci, E.L. Self-Determination theory and the facilitation of intrinsic motivation, social development, and well-being. Amer. Psychol. 2000, 55, 68-78. [CrossRef]

50. Deci, E.; Ryan, R.M. The "What" and "Why" of goal pursuits: Human needs and the self-determination of behavior. Psychol. Inq. 2000, 11, 227-268. [CrossRef]

51. Mao, L.L.; Huang, H. Social impact of formula one chinese grand prix: A comparison of local residents' perceptions based on the intrinsic dimension. Sport Manag. Rev. 2016, 19, 306-318. [CrossRef]

52. Woosnam, K.M.; Van Winkle, C.M.; An, S. Confirming the festival social impact attitude scale in the context of a rural texas cultural festival. Event Manag. 2013, 17, 257-270. [CrossRef]

53. Faulkner, B.; Tideswell, C. A Framework for monitoring community impacts of tourism. J. Sustain. Tour. 1997, 5, 3-28. [CrossRef]

54. Yolal, M.; Gursoy, D.; Uysal, M.; Kim, H.; Karacaoğlu, S. Impacts of festivals and events on residents' well-being. Ann. Tour. Res. 2016, 61, 1-18. [CrossRef]

55. Oshimi, D. Social impacts of mega-sporting events: A test in the Tokyo 2020 Olympic and Paralympic Games. Jpn. J. Sport Manag. 2020, 12, 1-19. [CrossRef]

56. Hu, L.T.; Bentler, P.M. Cutoff criteria for fit indexes in covariance structure analysis: Conventional criteria versus new alternatives. Struct. Equ. Model. Multidiscip. J. 1999, 6, 1-55. [CrossRef]

57. Oshio, A. Hajimete no Kyobunsankozo Bunseki Amos Ni Yoru Pasu Kaiseki; Tosho: Tokyo, Japan, 2014. (In Japanese)

58. Bollen, K.A. A new incremental fit index for general structural equation models. Sociol. Methods Res. 1989, 17, 303-316. [CrossRef]

59. Hair, J.F.; Black, W.C.; Babin, B.J.; Anderson, R.E.; Tatham, R. Multivariate Data Analysis; Pearson Prentice Hall: Hoboken, NJ, USA, 2010.

60. Coalter, F. Sport a Wider Social Role: Whose Keeping the Score? Routledge: London, UK, 2007.

61. Brown, C.; Pappous, A. Are mega-events a solution to address physical inactivity? Interrogating the London 2012 Paralympic sport participation legacies among people with disabilities. Eur. J. Sport Soc. 2021, 18, 18-43. [CrossRef]

62. Filo, K.; Funk, D.; O’Brien, D. The meaning behind attachment: Exploring camaraderie, cause, and competency at a charity sport event. J. Sport Manag. 2009, 23, 361-387. [CrossRef]

63. Pathare, S.; Vijayakumar, L.; Fernandes, T.N.; Shastri, M.; Kapoor, A.; Pandit, D.; Lohumi, I.; Ray, S.; Kulkarni, A.; Korde, P. Analysis of news media reports of suicides and attempted suicides during the COVID-19 lockdown in India. Int. J. Ment. Health Syst. 2020, 14, 1-9. [CrossRef] [PubMed]

64. Tanaka, T.; Okamoto, S. Increase in suicide following an initial decline during the COVID-19 pandemic in Japan. Nat. Human Behav. 2021, 5, 229-238. [CrossRef]

65. Ueda, M.; Nordström, R.; Matsubayashi, T. Suicide and mental health during the COVID-19 pandemic in Japan. medRxiv 2020, 3 , 1-21. [CrossRef]

66. Kim, H.J.; Gursoy, D.; Lee, S.-B. The impact of the 2002 World Cup on South Korea: Comparisons of pre- and post-games. Tour. Manag. 2004, 27, 86-96. [CrossRef]

67. Sato, S.; Kinoshita, K.; Kim, M.; Oshimi, D. The effect of Rugby World Cup 2019 on residents' psychological well-being: A mediating role of psychological capital. Curr. Issues Tour. 2020, 1-15. [CrossRef] 